\title{
Frank Kolb
}

(Tybinga)

\section{O NARUSZANIU PODSTAWOWYCH ZASAD POSTĘPOWANIA NAUKOWEGO}

\section{„Wzgórze przeznaczenia archeologii” górą skandalu}

DOI 10.14746/SEG.2014.9.13

\begin{abstract}
The article discusses ethical aspects and thoroughness of scientific research on the example of German excavations in Troy, conducted in 1988 by a team from Tübingen University. The author demonstrates how archaeologists became entangled in various relationships with polictical and economic circles, which subsequently yielded an interpretation of findings which ensured financial and media support. The text is an emphatic call for independence and objectivity of scientific investigations that should remain free of any pressure. Although the paper relies on an example from the milieu of archaeologists. historians and classical philologists, the appeal of the authors is a universal one.
\end{abstract}

\section{Key words}

Troy, archaeology, Homer, Iliad, Trojan War, myth of Troy, media, politics, economy, manipulation 
Uporczywe $^{1}$ podtrzymywanie przez wcale niemałą i przy tym wpływową grupę mediów tybińskiego mitu o Troi nie jest jedynym wątpliwym aspektem tego skandalu naukowego. Jeszcze bardziej problematyczna jest tak naprawdę reakcja na te wykopaliska $\mathrm{w}$ określonych kręgach świata nauki. Co prawda przynajmniej w Niemczech nikt już trojańskiej wizji Manfreda Korfmanna i Joachima Latacza poważnie nie traktuje. Ale mimo to, z wyjątkiem kilku cytowanych w tej książce głosów, w środowisku archeologów na ten temat się milczy, a jeśli już, to w publikacjach całą sprawę się bagatelizuje; to z kolei budzi podejrzenia o współpracę. Qui tacet, consentire videtur. „Kto milczy, sprawia wrażenie, że się zgadza". W pewnym sensie dewiza ta przyszła z najwyższych kręgów, co znajduje potwierdzenie w słowach: „w Troi wykonano dobrą robotę, a przy interpretacji badań wykopaliskowych ścierać mogą się, co w nauce jest rzeczą naturalną, różne poglądy”. Czy niedopuszczalne z metodycznego punktu widzenia postępowanie, manipulowanie badaniami i rysunkami planów, jak i zafałszowywanie faktycznego stanu rzeczy nazwać można „dobrą robotą"? A wyciągane na tej podstawie wnioski tylko kwestią interpretacji? Niektórzy z naukowców określają spór o Troję jako rzecz niepotrzebną, niegodną i szkodliwą. Ci badacze powinni postawić sobie poważne pytanie, czy nie sensowniejsze byłoby jednoznaczne skierowanie tych zarzutów przeciwko naruszaniu podstawowych zasad postępowania naukowego, a nie przeciwko ich ujawnianiu.

\footnotetext{
${ }^{1}$ Przełożył Leszek Mrozewicz. Artykuł niniejszy stanowi jedenasty rozdział książki F. Kolba „Tatort «Troia». Geschichte - Mythen - Politik”, Schöningh, Paderborn etc. 2010. Jej polska wersja „Zmanipulowana «Troja». Historia — mity - polityka” ukaże się nakładem Wydawnictwa Nauka i Innowacje (Poznań) w roku 2015. Ze względu na uniwersalny charakter tego rozdziału, odnoszący się do etosu badań naukowych w ogóle, zdecydowaliśmy się na jego wcześniejsze zamieszczenie na łamach naszego czasopisma, z nadzieją, że dzięki temu dotrze do szerszego grona naukowego, nie tylko archeologów i historyków. Nie dokonaliśmy żadnych skrótów, aby Czytelnik miał świadomość, że jest to podsumowanie rozbudowanego dyskursu, prowadzonego na łamach książki. Wydawnictwu Nauka i Innowacje dziękujemy za wyrażenie zgody na odrębne opublikowanie tego tekstu (red.).
} 
Wielu archeologów słusznie uważa, że rzeczą konieczną jest domaganie się jasnego pokazywania stosowanej metody. Brigitte Kull, niegdyś współpracująca z Manfredem Korfmannem, stwierdziła, że „dominujący obraz zabudowy dolnego miasta, w znacznej mierze wymyślony, musiał bezwzględnie doprowadzić do jego krytyki. Wywołała ona jednak różne dyskusje, które dotykają bezpośrednio podstaw naszej dyscypliny, a to warte jest sporu". Stefanie Samida, zatrudniona wcześniej w tybińskim Instytucie Archeologii Pradziejowej i Wczesnohistorycznej (Institut für Ur- und Frühgeschichte), ze sporu o Troję wyciąga wniosek, że „niejasne zasady, stosowane przy naukowym 'odczytywaniu’ źródeł archeologicznych, powinny doczekać się, w ramach różnych specjalizacji, odrębnej dyskusji”.

Archeolog z Frankfurtu (nad Menem), prowadzący prace wykopaliskowe w Priene w Azji Mniejszej, Wulf Raeck, wskazał jednoznacznie, w recenzji wydawniczej niemieckiej wersji mojej książki, na wyraźne w przypadku wykopalisk w Troi „polityczne i gospodarcze interesy i naciski” oraz na „problem finansowania (prowadzonych tam) badań”2. Byłoby to nad wyraz godne pożałowania, gdyby naukowość Projektu Troja zeszła na plan drugi. Sven Kellerhoff (Die Welt, 16.02.2004) nie mógł „pozbyć się wrażenia [...], że w Projekcie Troja efekty badań archeologicznych interpretowane są według uznania” oraz że „rzeczywistość i fantazja są tak samo trudne do rozróżnienia, jak w licznych literackich adaptacjach wątków homeryckich". W rezultacie doszedł do wniosku, że Niemiecka Wspólnota Badawcza (Deutsche Forschungsgemeinschaft), która finansuje opracowanie znalezionych obiektów, powinna jeszcze raz sprawdzić, czy Korfmann i jego zespół przestrzegają „zasad dobrej praktyki naukowej”. Jednym z obowiązków naukowców jest „konsekwentne wątpienie w efekty nawet własnych badań". W każdym razie rzekome wyniki badawcze Projektu Troja dostarczają ku temu mnóstwa powodów. Można by jeszcze

${ }^{2}$ H. Parzinger, Die Zeit 28, 05.07.2007, s. 42; D.P. Mielke, Archäologie in Deutschland 6, 2007, s. 77; U. Veit, Über die Grenzen archäologischer Erkenntnis und die Lehren der Kulturtheorie für die Archäologie, [w:] U. Veit, T. Kienlin, C. Kümmel, S. Schmidt, Münster etc. (red.), Spuren und Botschaften. Interpretationen materieller Kultur, Tübinger Archäologische Taschenbücher 4, Waxmann, Münster 2003, s. 486; B. Kull, „Ya tutarsa ...”. Krieg um Troia und die Landesarchäologie - Ein essayistischer Kommentar, [w:] R. Aslan, S. Blum, G. Kastl, F. Schweizer, D. Thumm (red.), Mauerschau. Festschrift für M. Korfmann zum 60. Geburtstag, 3, Remshalden-Grünbach 2002, s. 1182; S. Samida, Archäologische Quellen: Zwischen historischer Realität und historischer Fiktion. Anmerkungen zur Troia-Debatte, Archäologisches Korrespondenzblatt 36, 2006, s. 42-43; W. Raeck, Ilios als Stein des (Denk-)Anstoßes. Bemerkungen zu Frank Kolbs Buch «Tatort Troia», Gymnasium 118, 2011 (cytat na s. 383). 
zapytać, dlaczego nie odwołałem się do Komisji Etyki Uniwersytetu Tybińskiego czy chociażby jej odpowiednika w Niemieckiej Wspólnocie Badawczej. Zrezygnowałam $z$ tego, ponieważ można było się obawiać, mając na uwadze zbudowaną przez Korfmanna gęstą sieć powiązań, że te wyraźne naruszenia zasad naukowego postępowania zostaną potraktowane przez opiniodawców albo jako przeoczenie, albo jako zwykła przesada, albo też jako niedostrzeżone przez archeologów zaniedbania ich współpracowników, co skutkowałoby usprawiedliwieniem i zbagatelizowaniem sprawy. Przypomnijmy pokrótce niektóre $\mathrm{z}$ przedstawionych $\mathrm{w}$ poprzednich rozdziałach przykładów: przez osiem lat wskazywano na niewielki odcinek muru, z widocznym od początku otworem kanału, jako sensacyjne odkrycie muru obronnego dolnego miasta; przy tej okazji dokonano manipulacji rysunkowej na planie, przez zatuszowanie odpowiednio dobranymi kolorami różnych chronologicznie faz budowlanych domów, fałszywie też naszkicowano, niezgodnie z osiągniętym wynikiem badań, linię przebiegu rzekomego rowu obronnego (fosy); ignorowano badania w zakresie przemian środowiska naturalnego, co ma związek z ostatnim przykładem i z 'podziemną kopalnią wodną, ponieważ nie odpowiadały założonej przez odkrywców tezie; przemilczano fakt, że to już Carl W. Blegen znalazł pod jedną z budowli Troi VI ów rzekomy rów obronny, co oznacza, że to nie Korfmann, jak się propaguje, był rzeczywistym jego odkrywcą; zaniechano weryfikacji własnych ustaleń poprzez założenie odpowiednich sondaży, jak chociażby od strony zachodniej, na linii przyjmowanego przebiegu rzekomego rowu obronnego; przy tak zwanych rekonstrukcjach nie uwzględniono dokładnie wyników badań wykopaliskowych, na przykład w przypadku tak zwanej bramy południowej; po części nieprawidłowo podawano wymiary, vide rzekomy rów obronny; dopasowywano datowanie do przyjętej chronologii historycznej, czego dowodzi dolny rów obronny z okresu późnobrązowego, lub też rzekomy bastion Troi II; i w końcu ogłaszano te niby-osiągnięcia naukowe, podczas gdy można by mówić co najwyżej o spekulacjach i hipotezach.

Wytyczne Niemieckiej Wspólnoty Badawczej, ale także Uniwersytetu Tybińskiego, dotyczące zasad przestrzegania dobrej praktyki postępowania naukowego, występek tego typu określają jednoznacznie: „do złamania norm naukowych dochodzi wtedy, gdy przez świadome działanie bądź w wyniku rażących zaniedbań zafałszuje się wyniki badań [...]". I w kolejnym paragrafie: „Zachowanie niezgodne z normami badań naukowych [...] występuje zwłaszcza wówczas, gdy w określonym kontekście naukowym, umyślnie bądź w wyniku rażących zaniedbań, dopuszczono się wytworzenia danych, zafałszowania danych lub też dowolnego przemieszania danych”. Pod pojęciem „zafałszowa- 
nia danych” rozumie się „dobieranie i odrzucanie, bez ich (wcześniejszego) upublicznienia, wyników nieodpowiadających (przyjętej koncepcji)”. Wytyczne Niemieckiej Wspólnoty Badawczej zawierają poza tym postulat „postępowania lege artis [...], przestrzegania bezwzględnej uczciwości w odniesieniu do osiągnięć [...] poprzedników [...], konsekwentnego weryfikowania własnych ustalen"”.

Ostatnią wytyczną kierownictwo tybińskich wykopalisk w Troi prawie całkowicie ignorowało i jeśli niesprawdzony jeszcze wynik odpowiadał przyjętej wcześniej koncepcji, to wówczas, jak widzieliśmy, raczej rezygnowano z jego weryfikacji. Podejmowano ją dopiero pod presją gwałtownej krytyki, która odkrywcom nie pozostawiała wyboru. Wywoływała bowiem niepokój wśród uczestników prac wykopaliskowych, a w ostatecznym rezultacie zapewne również opiniodawcy Niemieckiej Wspólnoty Badawczej niezbyt skłonni byli uznać twierdzenia archeologów za właściwe.

Czego można oczekiwać od archeologa odkrywcy, gdy na sympozjum poświęconym Troi sam o sobie stwierdza: „Wszystko, co mówię, całkowicie mnie przekonuje!"? O odkrywcy, który, wsparty przez swego mentora Joachima Latacza, tak oto zniesławiał krytyków: „Mamy tu niemal wyłącznie do czynienia z osobami niekompetentnymi, które są przekonane, że muszą, sięgając po ogólne, teoretyczne pomysły o przeważnie destrukcyjnym zamiarze, grzebać w pragmatycznie działającym modelowym przedsięwzięciu solidnej niemieckiej tradycji naukowej [...]. Jak na to reagować mają ci badacze, którzy reprezentują właściwe dyscypliny? Czy należy mieć im za złe, że z osłupienia milczą?”" . W jakiejś mierze było to przejawem konsekwencji, gdy zarówno Manfred Korfmann, jak i Joachim Latacz zapowiedzieli, w związku z sympozjum o Troi, że nie wezmą udziału w kolejnych panelach dyskusyjnych oraz nie będą przygotowywać żadnych publikacji wspólnie z przedstawicielami drugiej strony.

Jak zauważył jeden z krytyków, Manfred Korfmann wcale nie uważał polemiki z argumentami drugiej strony za konieczną. Reprezentował pogląd, „że właściwie tylko kopiący w Troi są w stanie ocenić, co tak naprawdę na wzgórzu Hisarlik odkopano i odpowiednio to zinterpretować [...]. Brzmi to tak, jakby tylko dla siebie i swego najbliższego grona rezerwował prawo tworzenia obrazu

\footnotetext{
${ }^{3}$ Deutsche Forschungsgemeinschaft. Sicherung guter wissenschaftlicher Praxis. Denkschrift, Weinheim 1998, zwłaszcza s. 7; Wytyczne Niemieckiej Wspólnoty Badawczej z 4.12.2002; Uchwała Senatu Uniwersytetu Tybińskiego (Eberhard-Karls Uniwersität z 25.05.2000).

${ }^{4}$ Frankfurter Allgemeine Zeitung, 22.02.2002.
} 
Troi z okresu brązu”. Mając wsparcie w Joachimie Lataczu, uznał także, że nie jest konieczne, aby musiał tłumaczyć się z zastosowanej metody naukowej. Jeśli ktoś oświadcza, że „z ziemi wydobywamy historię wraz z jej kontekstem ekologicznym, ekonomicznym i społecznym", to z całą pewnością nie ma najmniejszego pojęcia o problemach metodycznych własnej dyscypliny ${ }^{5}$.

Dążeniu do monopolu interpretacyjnego zawsze towarzyszyło stwierdzenie, że archeolodzy pradziejowi stosują szczególne, „własne metody”. „My natomiast poruszamy się niekoniecznie w obrębie tylko nauk historycznych".

Przestrzeń argumentacji naukowej zamknęła się jednak całkowicie w chwili, gdy nastąpiło odwołanie się do „zaufania”, jako ochrony przed krytyką́. „Zaufanie" nie jest doprawdy żadną kategorią naukową - wręcz odwrotnie: jest nią krytyka! Nasuwa się oczywiście pytanie, czym archeolog odkrywca, Manfred Korfmann, uzasadnił szczególność metod badawczych archeologii pradziejowej. Najpierw odmienną, rzekomo specyficzną jakością wiarygodności badań: „Teksty powstają z reguły z określoną intencją. Przywołajmy chociażby Liwiusza, który ekspansję państwa rzymskiego starał się uzasadnić etycznie i religijnie. Teksty takie, a przynajmniej wiele $\mathrm{z}$ nich, wprowadzają w błąd, ale takie jest ich zadanie. W przypadku archeologii, czerpiącej wiedzę z prac wykopaliskowych, warstwa spalenizny eksplorowanej osady jest, patrząc przez pryzmat jej powstania, po prostu wiarygodna" ${ }^{\prime}$. Nie ma wątpliwości, że źródła pisane mogą być subiektywne i tendencyjne, ale nie jest to bynajmniej równoznaczne z zamiarem „wprowadzania w błąd”. Poza tym $\mathrm{w}$ dziele literackim znajdziemy nie tylko przekaz zamierzony, ale również nieprzewidziany. Jest to w jakimś sensie „pozostałość”, która w istocie swej niczym nie różni się od warstwy spalenizny czy fragmentu ceramiki. A przy tym warstwa spalenizny wcale nie jest „wiarygodna”, a na pewno swą wiarygodnością nie „przebija” żadnego świadectwa pisanego. A to dlatego, że wymaga

${ }^{5}$ K. Simon, Badische Zeitung, 22.03.2002; M. Korfmann, Die Tageszeitung, 07.05.2005.

${ }^{6}$ Schwäbisches Tagblatt, 22.11.2003; list okólny do 'Przyjaciół Troi’ z dnia 12.09.2004; M. Korfmann, Introduction - Troia and the Natural Sciences, [w:] G.A. Wagner, E. Pernicka, H.-P. Uerpmann (red.), Troia and the Troad. Scientific Approaches, Berlin-Heidelberg-New York 2003, s. 2-4; por. G. Weber, Neue Kämpfe um Troia. Genese, Entwicklung und Hintergründe einer Kontroverse, Klio 88, 2006, s. 23, przyp. 96.

${ }^{7}$ M. Korfmann, Troia im Lichte der neuen Forschungsergebnisse (Reden an der Universität Trier 2), Trier 2004, s. 12; o problemach natury metodologicznej archeologii pradziejowej zob. np. M.K.H. Eggert, Prähistorische Archäologie. Konzepte und Methoden, wyd. 3., TübingenBasel 2008; idem, S. Samida, Ur- und Frügeschichtliche Archäologie, Tübingen 2009, zwłaszcza s. $48-57$. 
ona, równie jak tekst Liwiusza, tak samo wyjaśniającej, to znaczy historycznej interpretacji, podobnie jak informacje zawarte w dziele rzymskiego historyka. Na marginesie: przekazuje on niezliczoną ilość o wiele bardziej „prawdziwych", niekwestionowanych faktów. Warstwa spalenizny nie jest, abstrahując od faktu, że powstała w wyniku pożaru, w żadnym wypadku obiektywna. Jej wymowa historyczna zależy od sposobu sformułowania pytania oraz od wiedzy archeologa, jak również jego przygotowania metodologicznego. Od tych założeń nie ma ucieczki w obszar rzekomo specyficznych metod archeologii pradziejowej $^{8}$. Nie istnieją żadne „własne” metody archeologii w znaczeniu ogólnym, a tym bardziej w przypadku archeologii pradziejowej. Już samo mówienie o „wiedzy wykopaliskowej” jest czymś całkowicie błędnym. Kopanie jest rzemiosłem, techniką, ale nie nauką i dlatego nie jest wykładane jako przedmiot uniwersytecki. Jako takie dostarcza tylko znalezisk i możliwości badań, ale nie wiedzy. Ta tworzy się w następstwie historycznej interpretacji wyników prac wykopaliskowych. Dlatego archeolodzy pradziejowi uważają siebie pod każdym względem za historyków, a nie tylko 'kopaczy'. Terminu archaiologia jako pierwszy użył grecki historyk Tukidydes, w znaczeniu „historia starożytna”. Archeologia jest nauką historyczną - niczym więcej!

$\mathrm{Na}$ tle innych form badania przeszłości udział przedstawicieli nauk przyrodniczych w pracach wykopaliskowych nie przysparza tym ostatnim większej naukowości. Po pomoc naukowców przyrodników sięga się także w przypadku innych dyscyplin humanistycznych, w tym historyczno-filologicznych. Z wykorzystaniem metod chemicznych opracowuje się na przykład palimpsest lub za pomocą promieni laserowych bada kamień, aby odczytać niewidoczne już gołym okiem pozostałości liter. Dodajmy, że historycy z powodzeniem prowadzą badania terenowe, w których uczestniczą także naukowcy przyrodnicy. Ale informacje, których dostarczają, stanowią tylko zespół danych, nieodbiegający od innych. Poza tym nie należy przeceniać wiarygodności wyników badań przyrodniczych, jeśli nie zostały wsparte odpowiednimi eksperymentami. Dotyczy to na przykład badań nad pochodzeniem metali, do czego dysponujemy, na tle potencjalnie dużo większej liczby kopalń, w części tylko odkrytych bądź przebadanych, zbyt małą ilością danych. Dotyczy to także datowania z pomocą metod węgla radioaktywnego bądź dendrochronologii. Badanie metodą ra-

${ }^{8}$ Por. F. Kolb, Archäologie und Geschichte. Ein Beitrag zur Methodologie, [w:] N. Kreutz, B. Schweizer (red.), Tekmeria. Archäologische Zeugnisse in ihrer kulturhistorischen und politischen Dimension. Beiträge für Werner Gauer, Paderborn 2006, s. 147-154. 
diometryczną zaprawy murarskiej z wielkiej piramidy faraona Chufu w Gizie wykazało, że zawiera ona w sobie elementy starsze o około 400 lat od okresu jego panowania. Może to mieć związek z tym, że do przygotowania zaprawy użyto także materiału organicznego pochodzącego z dużo wcześniejszego okresu. Zamiast wywoływać wrażenie, że samo zastosowanie metod przyrodniczych przyczyni się w jakiejś mierze do rozwiązania problemów historycznych, kierownictwo wykopalisk w Troi powinno było wskazać, że metody te nie tylko dostarczają nowych danych, ale przysparzają także nowych problemów interpretacyjnych. Henryk Schliemann, mimo przeprowadzonych badań przyrodniczych, nie uniknął błędów. Nie uniknęła ich również ekipa Manfreda Korfmanna.

Współpraca z przyrodnikami nie zmienia faktu, że rozstrzygające metodyczne etapy historycznej analizy znaleziska lub przeprowadzonych badań wymagają odpowiedniego wysiłku intelektualnego, i w obrębie nauk humanistycznych, łącznie z archeologią, są takie same. Obojętne, czy będziemy mieli do czynienia $\mathrm{z}$ rękopisem $\mathrm{z}$ klasztornej biblioteki, inskrypcją bądź papirusem, czy też ze stanowiskiem osadniczym, domem, grobem czy też innym obiektem, procedura gruntownej analizy każdego z tych 'dokumentów' pozostaje każdorazowo taka sama. Dotyczy to zarówno edycji dokumentu ze wszelkimi koniecznymi uzupełnieniami, jak i jego interpretacji. Krytyka tekstu w przypadku dokumentu pisanego odpowiada krytycznemu postępowaniu badawczemu w archeologii; stratygrafia przebadanego stanowiska odpowiada filiacjom rękopisu, względnie historycznym warstwom tekstu. Znakom krytycznym, stosowanym przy edycji dokumentu pisanego, odpowiada zróżnicowanie zachowanych i niezachowanych, przypuszczalnych i uzupełnionych odcinków muru, zaznaczonych na planach linią ciągłą, przerywaną lub wykropkowaną, albo też zaznaczoną różnymi kolorami. Rekonstrukcja wyglądu przebadanego obiektu archeologicznego i jego chronologii bazuje, podobnie jak w przypadku tekstu, na znajomości podobnych zjawisk oraz typologicznej oraz formalnej bliskości.

Element subiektywny w równej mierze pojawia się przy krytyce tekstu, czy ogólnie źródła, w obrębie wszystkich dyscyplin filologiczno-historyczno-archeologicznych. W trakcie interpretacji tekstu, znaleziska czy odsłoniętego obiektu bezustannie mieszają się ze sobą zarówno wiedza historyczna, indukcja logiczna i znajomość analogii, jak i wreszcie intuicja badawcza. To właśnie te hermeneutyczne komponenty mają wpływ na końcowe stadium rekonstrukcji historycznej: $\mathrm{z}$ analizy pojedynczych dokumentów tworzy się $\mathrm{w}$ rezultacie jeden ogólny obraz historyczny. Niemniej od pierwszego kroku, od opracowania 
dokumentu, aż po jego analizę w kontekście jemu podobnych, zmniejsza się stopień jego wymierności i dokładności, a dla odmiany wzrasta stopień subiektywizmu. Dotyczy to także archeologii praktycznej. Na etapie tworzenia dokumentacji elementy hipotetyczne czy wręcz spekulacyjne, bądź też jakiekolwiek powzięte z góry uprzedzenia, z reguły nie wchodzą w rachubę. Gdy jednak dochodzi do określenia historycznej roli badanego obiektu, to wówczas różne odcienie spekulacji wprost fatalnie wpływają na dalszą dyskusję. Ale również stawiana hipoteza wymaga konkretnych punktów zaczepienia w postaci tekstowego względnie archeologicznego dowodu. Nawet spekulacja musi zawierać się w ramach pewnych możliwości, jeśli ma być naukowo zaakceptowana. Dla przykładu "Związek Hanzeatycki” w drugim tysiącleciu przed Chr. na pewno w tych ramach się nie mieści.

Jak szkodliwy wpływ na dokumentowanie i interpretację znalezisk oraz wyników badań może mieć, powstałe na bazie przekazów literackich i mitycznych, z góry obecne nastawienie wobec „odkrywanej” rzeczywistości, dobrze ilustrują badania wykopaliskowe na wzgórzu Palatyn w Rzymie, prowadzone przez Andreę Carandiniego. Podjęto je z określonym celem: znaleźć 'miasto Romulusa'. Dlatego mniejsze bądź większe tarasy na zboczu wzgórza uznano za pozostałość następujących po sobie murów obronnych, kilka śladów po palach za resztki palisady, równoznacznej z przebiegiem wytyczonego przez Romulusa pomerium, a rów odwadniający za pozostałość po świętej bruździe, którą Romulus wytyczył wokół osiedla. Datowanie ceramiki dopasowywano do wymogów chwili. Krytyka interpretacji Andrei Carandiniego przedostała się do wiadomości publicznej stosunkowo późno, w znacznej też mierze ograniczyła się do kręgu angielskojęzycznego. Wpływy osobiste, powiązania przyjacielskie, układy i polityczne umocowania zagranicznych Instytutów Archeologicznych w Wiecznym Mieście, doprowadziły do tego, że chociaż owe rzekome wyniki badań wykopaliskowych jeszcze dzisiaj określane są w kuluarach jako bzdurne, to jednak znalazły miejsce w najnowszych opracowaniach, jak na przykład w encyklopedii antyku „Der Neue Pauly”.

\footnotetext{
${ }^{9}$ O problematyce datowania z wykorzystaniem metod badań przyrodniczych zob. N. Kokkinos, Ancient Chronography, Eratosthenes and the Dating of the Fall of Troy, Ancient West and East 8, 2009, s. 51 z podaniem literatury; o wykopaliskach Carandiniego zob. T.P. Wiseman, Journal of Roman Studies 91, 2001, s. 182-183; o 'recepcji': Der Neue Pauly 10, 2001, s. 1084 s. v. Roma III. Topographie und Archäologie der Stadt Rom (Heinzelmann); por. F. Kolb, Rom. Die Geschichte der Stadt in der Antike, wyd. 2, München 2002, s. 56-58, 752-753.
} 
Jak widać, obraz ten zgodny jest z tym, co zauważyć można na tybińskich wykopaliskach w Troi. Bez tradycji literackiej, bez Homerowej Iliady, „interpretacja ruin na wzgórzu Hisarlik wyglądałaby zupełnie inaczej” ${ }^{10}$. Ale Manfred Korfmann miał na uwadze tylko jeden cel: udowodnić istnienie wielkiej homeryckiej «Troi».

Dlatego przykrycie niewielkiego kanału wodnego zinterpretowano jako fragment założeń fortyfikacyjnych, czyli element muru obronnego miasta dolnego, stanowiącego część metropolii handlowej. Do dzisiaj też rowy, które pełniły albo na pewno, albo z dużym prawdopodobieństwem, funkcję kamieniołomu, kolektora odwadniającego i rezerwuaru wody, uważane są za część systemu fortyfikacyjnego.

Przykłady te powinny wystarczyć, aby wykazać niedorzeczność twierdzenia, że wykopaliska, w przeciwieństwie do źródeł pisanych i sposobu ich interpretacji, dostarczają obiektywnych danych, zasługujących na zaufanie. Rzecz ma się raczej odwrotnie. Dokument pisany nie zmienia się, w każdej chwili można zajrzeć do oryginału, jego edycja podlega krytycznej weryfikacji ze strony wielu badaczy. Inaczej wygląda to w przypadku wykopalisk. Ich 'edycja' „W każdym przypadku możliwa jest tylko jeden, jedyny raz; a to dlatego, że $\mathrm{w}$ następstwie eksploracji obiektu i wyodrębnienia z niego różnych obiektów ruchomych, jedność znaleziska z jego kontekstem ulega bezpowrotnemu zniszczeniu”. A przy tym to zawsze archeolog odkrywca decyduje o tym, „które $\mathrm{z}$ detali $\mathrm{z}$ określonego kontekstu in situ warte są zadokumentowania, a które nie" ${ }^{11}$. Nie ma więc żadnej niezależności 'faktów' archeologicznych od archeologa. Likwidacja eksplorowanego stanowiska w kombinacji z jego decyzją, które z 'faktów' należy wybrać, stwarza ewidentne zagrożenie. Z jednej strony powstaje ryzyko, zwłaszcza na dużych stanowiskach archeologicznych, że nie wszystkie osoby uczestniczące w pracach są na tyle kompetentne, by sumiennie sporządzić dokumentację badawczą. $Z$ drugiej natomiast zapewne w żadnej z dyscyplin nauk humanistycznych nie ma tylu okazji i prób manipulacji wynikami badań, co właśnie w archeologii praktycznej (wykopaliskowej), ale bynajmniej nie oznacza to, że pokusie tej ulega wielu archeologów! Staje się ona jednak tym większa, im bardziej w badaniach, w których z góry określono ich

\footnotetext{
${ }^{10}$ S. Samida, Archäologische Quellen, s. 42.

${ }^{11}$ H.G. Niemeyer, Einführung in die Archäologie, Darmstadt 1968, s. 55; M.K.H. Eggert, Über Feldarchäologie, [w:] R. Aslan, S. Blum, G. Kastl, F. Schweizer, D. Thumm (red.), Mauerschau, 1, s. 26.
} 
cel, dąży się do osiągnięcia pożądanego wyniku. Dochodzi do tego wątpliwe etycznie niepisane prawo, że członkowie ekipy nie powinni wypowiadać się o swoich wykopaliskach krytycznie czy wręcz negatywnie. Złamanie tej zasady postawiłoby pod znakiem zapytania ich dalszą karierę zawodową lub nawet doprowadziło do jej ruiny. Podjętą przez Manfreda Korfmanna próbę zignorowania krytycznej metody filologiczno-historycznej potraktować należy jako ucieczkę w stronę całkowicie dowolnego sposobu interpretacji. W połączeniu z wizją późnobrązowego osiedla na wzgórzu Hisarlik jako wspaniałego miasta rezydencjonalnego i pałacowego oraz metropolii handlowej, co nie ma żadnego odzwierciedlenia w wynikach badań, a także z absurdalnym twierdzeniem, motywowanym politycznie, że na Hisarliku odkryto korzenie kultury europejskiej, metodę postępowania Manfreda Korfmanna w znacznym stopniu uznać trzeba za pseudonaukę.

Pojęcie to we współczesnej teorii naukowej wzbudza kontrowersje, ale raczej tylko dlatego, że nie wszyscy chcą zagłębiać się w istotę rzeczy. Dotyczy to w pierwszej kolejności barier między poszczególnymi dyscyplinami. Podkreśla się, że na przykład alchemia, frenologia i inne „dyscypliny”, o bardzo kontrowersyjnej „naukowości”, w ostatecznym rozrachunku przyczyniły się do rozwoju współczesnej nauki. Wskazuje się także na te teorie i działania praktyczne, które niegdyś spełniały kryteria obiektywizmu i racjonalności, ale dzisiaj uważane są za wątpliwe. W efekcie granica między tym, co określa się jako naukę, a tym, co jest nienaukowe, traktowana jest relatywnie i mgliście. W chwili, gdy granica ta, niewyraźna co prawda, ale jednak słuszna, znika z pola widzenia, zarzut 'pseudonaukowości', który nie ma uzasadnienia w przyjętych normach, musi być potraktowany jako osąd subiektywny, wynikający z konkretnych pobudek. Stwierdzenie, że coś jest 'pseudonaukąa, zawsze jest wynikiem oceny zewnętrznej, a to z kolei służy za argument, aby w miejsce tego terminu używać określenia „nauka alternatywna”. Nie zapomnijmy przy tym, przy wyciąganiu takich wniosków, że wpływ na odrzucenie kryteriów w przypadku nauk epistemologicznie ugruntowanych, na rzecz odwołania się do motywacji politycznych czy etyczno-moralnych, ma również duch danego czasu ${ }^{12}$.

Należy przede wszystkim pozostać przy tym, że do postawienia nie tylko jakiejkolwiek tezy, lecz także hipotezy, potrzebne są odpowiednie dowody. Jeśli tych, z niedających się wyjaśnić względów, brakuje, to taką tezę czy hipotezę

${ }^{12}$ Zob. materiały zawarte [w:] D. Rupnow et alii (red.), Pseudowissenschaft. Konzeptionen von Nichtwissenschaftlichkeit in der Wissenschaftsgeschichte, Frankfurt/M. 2008. 
należy z góry potraktować jako zafałszowaną. Jeśli na przykład zakłada się, że $\mathrm{w}$ danym miejscu istniało duże antyczne lub prahistoryczne miasto o zabudowie kamiennej, to należy oczekiwać pojawienia się odpowiednich pozostałości osadniczych i ton gruzu. Jeśli czegoś takiego nie znaleziono, koncepcja taka jest nie do utrzymania ${ }^{13}$. Nie można słuszności danej tezy czy hipotezy uzasadniać konkretną ilością osób za nią się opowiadających. Jeśli Joachim Latacz posługuje się stwierdzeniem, że tylko „mały krąg niedowiarków” wątpi w poglądy Manfreda Korfmanna i jego, to tym samym stawia naukę na równi z demokratycznym system rozstrzygania większością głosów.

Postępowanie naukowe polega na tym, że od preferowanych wniosków, jeśli pojawiają się dowody im zaprzeczające, dobrowolnie się odstępuje, względnie je modyfikuje. Jak słusznie stwierdził David Hume ${ }^{14}$ : „Mądry człowiek swoje przekonanie uzależnia od (istniejących) świadectw". Owa twórcza elastyczność w obchodzeniu się ze świadectwami odróżnia naukę od pseudonauki. Oto co stwierdza Garrett G. Fagan: „Za pseudoarcheologa [...] uznać można tego, kto świadomie, zamiast zweryfikować swój punkt widzenia, ignoruje zaprzeczające jego tezie dane lub też świadomie pomija, względnie bliżej nie analizuje, wynikających z kontekstu (badań) wniosków z obawy, że wymusi to konieczność odrzucenia z góry założonego wyniku. Przy czym ta niewłaściwa postawa w obu przypadkach musi być zjawiskiem systematycznym. Potraktowanie jednak jako pseudoarcheologów pionierów tej dyscypliny naukowej, jak na przykład Henryka Schliemanna [...], tylko dlatego, że kierowała nimi romantyczna wizja, a kontekstowi poświęcali dużo mniej uwagi w porównaniu $\mathrm{z}$ badaczami dzisiejszymi, byłoby całkowicie niesprawiedliwe. $\mathrm{W}$ tamtym czasie nie była to jeszcze dyscyplina metodycznie dojrzała, brak było ustalonych zasad postępowania w terenie [...], jej cechą charakterystyczną było relatywnie mało subtelne postępowanie interpretacyjne”. Następnie Garrett G. Fagan dodaje: „Pseudoarcheologia [...] nie ogranicza się do nieprofesjonalnych pismaków $\mathrm{z}$ wysoce dziwacznymi wyobrażeniami o starożytności. Stanowić może także pułapkę dla wielu profesjonalnie wykształconych przedstawicieli środowisk akademickich, w sytuacji, gdy obowiązek prowadzenia uczciwych badań zderza

${ }^{13}$ P. Kosso, Introduction, [w:] G.G. Fagan (red.), Archaeological Fantasies, London-New York 2006, s. 10.

${ }^{14}$ D. Hume, An Enquiry Concerning Human Understanding, wyd. 9, Cambridge 1998 (wyd. pierwsze 1777), s. 73. 
się z ich egoizmem, motywacjami ideologicznymi czy też innymi osobistymi zapatrywaniami".

Ta definicja pseudoarcheologii odpowiada postawie Manfreda Korfmanna. Wraz z nim na ścieżkę pseudonauki wkroczył również Joachim Latacz. Cechą charakterystyczną pseudonauki jest bowiem także, zdaniem Fagana, zrzucanie, z jednoczesnym przywołaniem autorytetów, ciężaru dowodu na barki krytyków, mimo że to nie oni, lecz autor stwierdzenia ma obowiązek jego udowodnienia. Poza tym krytyka Garretta G. Fagana odnosi się również do książki Joachima Latacza „Troja i Homer”, ponieważ prezentowanie przypuszczenia najpierw jako możliwości, a następnie jako ustalonego faktu, jest pseudonauką. Zarzut ten Joachimowi Lataczowi postawili między innymi Joshua T. Katz i Johannes Haubold ${ }^{15}$.

Colin Renfrew pseudoarcheologią nazywa także, podobnie jak Garrett G. Fagan, nadużywanie nauki do celów politycznych. Jeśli archeologia pozostaje na usługach określonej ideologii politycznej, a osiągnięte w jej ramach wyniki badań dopasowywane są do wyrażonych wcześniej poglądów, to mamy do czynienia z pseudoarcheologią ${ }^{16}$. Jak można wykorzystać archeologię dla celów politycznych, co czynił Manfred Korfmann ze względu na Turcję, doskonale ilustrują nowsze badania archeologiczne w Indiach. „Nie tylko w [...] regularnych publikacjach, ale także na uniwersytetach, w szkołach i wobec opinii publicznej, nie wykluczając uznanych naukowców, intensywnie rozpowszechniany jest od około 1980 roku pogląd, że cywilizacja ludzka jako taka narodziła się w Indiach, mniej więcej dziesięć tysięcy lat przed Chr., że wszystkie języki świata wywodzą się od sanskrytu, że cywilizacja indyjska trwa nieprzerwanie od około 7500 przed Chr. i że Europa, zamieszkana przez narody mówiące językami indoeuropejskimi, zasiedlona została przez przybyszów znad Gangesu". W Indiach powstały jakoby najstarsze teksty ludzkości, tutaj dokonano wszystkich znaczących odkryć na polu nauki i technologii, włączając w to matematykę, medycynę, samoloty, rakiety i bombę atomową. Wiąże się to z legendą, że pierwszy wydawca Rigwedy, Max Müller, ukradł wszystkie 'indyjskie'

${ }^{15}$ G.G. Fagan, Diagnosing Pseudoarchaeology, [w:] idem (red.), Archaeological, s. 27-29 (z cytatem), 40-41; zob. recenzje książki J. Latacza, Troy and Homer: Towards a Solution of an Old Mystery, Oxford 2004: J.T. Katz, Journal of the American Oriental Society 125, 3, 2005, s. 423: "The more something is said, the more it is taken as fact in his "logical " schemes"; J. Haubold, Ancient West and East 8, 2009, s. 390-391.

${ }^{16}$ C. Renfrew, Foreword, [w:] G.G. Fagan (red.), Archaeological, s. XIII-XIV; por. G.G. Fagan, Diagnosing, s. 28. 
tajemnice, a Niemcy zrobili z tego użytek, budując samoloty i bombę atomową. W latach 1998-2004 władzę w Delhi sprawowały partie nacjonalistyczne, co dla takiego opisu indyjskiej historii, a zarazem wykorzystania w tym celu archeologii, okazało się wiatrem w żagle. Muzeum Narodowe w New Delhi zostało przeorganizowane zgodnie z potrzebami nowej ideologii i zaopatrzone w odpowiednie opisy. Aryjskiej ideologii Hindusu południowoindyjscy Tamilowie przeciwstawili teorię zaginionego kontynentu o nazwie Lemuria, który jakoby rozpadł się w wyniku katastrofy spowodowanej gigantyczną powodzią gdzieś między 6750 a 3300 przed Chr. Kontynent ten, w wyobrażeniach Tamilów ich praojczyzna, obejmować miałby Indie, Sri Lankę, Madagaskar i znaczne części Indonezji. Tam właśnie, zgodnie z wersją Tamilów, narodziła się cywilizacja. Mitologizacja dziejów indyjskich, podobnie jak tureckich, jest wynikiem poważnego kompleksu niższości, spowodowanego długim pozostawaniem pod obcym panowaniem. Jego rekompensatą, i to $z$ nadwyżką, ma być teza o Indiach jako najstarszej cywilizacji świata. W konstruowaniu tego mitu uczestniczyła nie tylko szeroko rozumiana opinia publiczna, ale również naukowcy, jak na przykład ówczesny dyrektor generalny Indyjskiego Instytutu Archeologicznego ${ }^{17}$. Ta interpretacja historii indyjskiej czy też świata wiąże się z przekonaniem postmodernistycznego dekonstruktywizmu, że nauki humanistyczne posługują się nie faktami, lecz pojęciami, które można w sposób dowolny akceptować lub odrzucać. Jak pokazuje indyjski przykład połączenia nacjonalizmu $\mathrm{z}$ dekonstruktywizmem, pseudonauka i postmodernizm nie są bynajmniej przeciwieństwem, jakby się to na pierwszy rzut oka wydawało. Pseudonaukę kojarzy się z reguły ze skrajną lekkomyślnością, postmodernizm ze skrajnym sceptycyzmem. W kuriozalny sposób obie te postawy mogą być ze sobą zbieżne. Najinteligentniejsi przedstawiciele pseudonauki, w sytuacji gdy pojawiają się wątpliwości co do zasadności i wiarygodności podstaw ich twierdzeń, wykorzystują argumenty postmodernizmu. Jednocześnie strona postmodernistyczna często odwołuje się do swego sceptycyzmu na tyle selektywnie, że niekiedy pogarda dla podstaw współczesnej nauki zbiega się z sympatią wobec tej czy innej odsłony pseudonauki. Oba te nurty niejako stykają się ze sobą w sformułowaniu sceptyka Francisa Bacona: „Człowiek woli wierzyć w to, co uznaje za prawdę". Niebezpieczne jest także, gdy pewien profesor europejskiej historii idei i metodologii historii na Uniwersytecie w Rostocku wzywa do „nie-

\footnotetext{
${ }^{17}$ M. Witzel, Rama's Realm. Indocentric Rewritings of Early South Asian Archaeology and History, [w:] G.G. Fagan (red.), Archaeological, s. 203-232.
} 
unikania gry z fikcją". Powołuje się przy tym na Tukidydesa: wplecione w jego narrację mowy polityków i dowódców wojskowych uważa błędnie za fikcję. Dla Tukidydesa był to tylko powszechnie wówczas akceptowany środek retoryczny, służący, podobnie jak we współczesnej historiografii argumentacja, wyjaśnieniu rozstrzygającej sytuacji historycznej ${ }^{18}$.

Uwikłanie się zawodowych archeologów w popularyzowanie pseudoarcheologii, nawet wtedy, gdy jest działaniem niezamierzonym, należy poddać zdecydowanej krytyce i refleksji metodycznej. Niektórzy archeolodzy, jeśli to tylko służy ich interesom, nie mają zahamowań przed wykorzystaniem dla swoich celów rzekomych tajemnic, cudów i skarbów kultury antycznej, i to w sposób nierzadko przekraczający powagę badań naukowych. Niezależnie od tego, czy czynią to tylko przed kamerami na użytek szerokiej publiczności, czy też po to, aby zrobić wrażenie na wspierających ich sponsorach bądź $\mathrm{w}$ celu pozyskania nowych, to jednak rozgrywają wówczas kartę pseudonaukowości. Opinia publiczna przyzwyczaja się, że z archeologią łączą się szczególnie bogate, sensacyjne odkrycia i rozwiązywanie starych tajemnic. Nie jest jednak w stanie dokonać rozróżnienia między archeologią naukową a pseudonaukową. Przykładem pseudonaukowych działań może być postać znanego brytyjskiego archeologa Jamesa Mellaarta. W roku 1958 podał do publicznej wiadomości informację o sensacyjnym odkryciu. Oto w Izmirze wiosną tego roku pewna kobieta, której tożsamości nie da się zweryfikować, pokazała mu w swoim domu przedmioty pochodzące $\mathrm{z}$ dwóch grobów z okolicy wioski Dorak, położonej w pobliżu «Troi». Domu, w którym James Mellaart przedmioty te rzekomo obejrzał, nie dało się odnaleźć, nie zgadzał się też podany przez niego adres. Ślady cywilizacji w sąsiedztwie Troi z artefaktami, podobnymi do znanych już z Hisarliku, musiały oczywiście wywołać duże poruszenie. Szybko się oczywiście okazało, że jedynym 'potwierdzeniem' istnienia tych znalezisk są rysunki Mellaarta, z których przynajmniej część nie była niczym innym, jak kopią obiektów znajdujących się

\footnotetext{
${ }^{18}$ R.J. Evans, Fakten und Fiktionen. Über die Grundlagen historischer Erkenntnis, Frankfurt-New York 1998, s. 212-243; A.D. Sokal, Pseudoscience and Postmodernism. Antagonists or Fellow Travelers?, [w:] G.G. Fagan (red.), Archaeological, s. 286-361; por. także B.G. Trigger, A History of Archaeological Thought, Cambridge 1989, s. 381: „Some of the more radical relativists have concluded that [...] they have the right to use archaeological data for any purpose that they wish. They see them as [...] providing material for fantasies about the past [...] or as propaganda to promote political or social causes"; F. Bacon, The New Organon, Cambridge 2000, s. 44; Markus Völkel, Frankfurter Allgemeine Zeitung, 09.04.2002.
} 
w muzeach tureckich. Jeden z jego byłych współpracowników, podobnie jak on zaprzyjaźniony z Agatą Christie, przyznał, że pomagał Mellaartowi w sporządzeniu odpowiedniego komunikatu. Jest zrozumiałe, że po rzekomych znaleziskach nie ma najmniejszego śladu, a całą historię należy umieścić wśród oszustw pseudoarcheologii. Nie jest przypadkiem, że pozostaje ona w związku z «Troją» (zob. Frankfurter Allgemeine Zeitung, 23.04.2008). Nie brakuje jednak, z drugiej strony, także dowodów godnej najwyższej pochwały uczciwości. Gdy właścicielka jednego z domów w Szkocji odkryła w ogrodzie kamienne płyty, powiadomiła archeologów. Na miejsce przybył zespół badaczy i w efekcie wielodniowej, starannej pracy ustalono, że jakoby są to pozostałości osiedla Wikingów sprzed tysiąca lat. Byłby to pierwszy dowód wzniesienia domów Wikingów na terenie Szkocji. Gdy jednak okazało się, że do kontekstu znalezisk należy także mający zaledwie kilkadziesiąt lat sprzęt gospodarstwa domowego i że odkopane stanowisko to zatopiona kamienna terasa, badacze podali do publicznej wiadomości, że ich „sensacyjne znalezisko archeologiczne" jest całkowitą porażką, co potwierdzili także w mediach (Schwäbisches Tagblatt, 09.01.2004). Dla Manfreda Korfmanna i aktualnego kierownictwa wykopalisk w Troi tak daleko posunięta uczciwość jest czymś całkowicie obcym. W dyskursie naukowym należy jednak domagać się jej przestrzegania jako czegoś oczywistego. W archeologii dochodzi czasami, pod presją konieczności zdobycia funduszy, do powstania, w efekcie połączenia poczucia pewności siebie, gotowości do manipulowania znaleziskami, potrzeby samodowartościowania oraz chęci zrobienia kariery, fatalnej wprost mieszanki. W przypadku wykopalisk w Troi pieniądze odegrały wielką rolę nie tylko $\mathrm{w}$ formie sponsoringu, lecz także z wpływów za katalog wystawy, książek popularnonaukowych i dystrybucję gry komputerowej 'Troja'. Dokonana przez Manfreda Korfmanna na koszt państwa (niemieckiego), a więc podatnika, 'powtórka' gotowej już wirtualnej 'rekonstrukcji' jego snu o Troi, dowodzi pozbawionego skrupułów polowania na pieniądze, co niestety w kręgach naukowych spotyka się raczej z uznaniem niż naganą.

Błędem byłoby sądzić, że świat akademicki i naukowy jest mniej skorumpowany niż inne środowiska. Narzucenie uniwersytetom zasad gospodarki rynkowej stan ten tylko pogłębiło. Przez dziesięciolecia profesorowie byli w stanie w miarę skutecznie blokować nonsensowne 'reformy', wymyślane przez polityków z obszaru edukacji i nauki. Wystarczyło przeczekać do łatwej do przewidzenia zmiany ministrów, z których każdy w pierwszej kolejności przystępował do czyszczenia podwórka, odwołując zarządzenia poprzednika. Ostatnio jednak, drogą finansowego szantażu i kuszenia nauczycieli akademickich 
pieniędzmi, te polityczne nonsensy wprowadzane są w życie. Zatrudnieni na uniwersytetach profesorowie nie są bynajmniej bohaterami, a już na pewno nie tworzą solidarnej wspólnoty.

Płacimy wysoką cenę za coraz bardziej jednoznaczne zrównywanie wiedzy i nauki ze zwykłym produktem rynkowym. Ideał niczym nieskrępowanego poznania, rzeczywista matka nauki, zagrożony jest, wobec masowego parcia w stronę praktycznego wykorzystania i stosowania wiedzy, odejściem w nicość. Niemały wkład w korumpowanie nobliwych struktur uniwersyteckich, a wraz z nimi także kultury nauki, łącznie z etyką naukową, mają politycy i menadżerowie życia naukowego. Trafnie sformułowała to na łamach Frankfurter Allgemeine Zeitung (24.11.2009) roku Heike Schmoll: „Nie prowadzi się już badań w celu uzyskania odpowiedzi na postawione pytanie badawcze, lecz po to, by móc pochwalić się uzyskaniem grantu. Wywołuje to poważne wątpliwości. Ale jest jeszcze gorzej: oto w miejsce kultury argumentacji pojawiła się kultura (przedkładania) wniosków (grantowych). Nie wolno już mówić o błędach i trudnościach, kara za niestaranie się o granty stała się rzeczą oczywistą". Autorka wskazuje także na środki zaradcze, mogące powstrzymać ten fatalny trend rozwojowy. Sprowadzają się one do powrotu do wcześniejszych relacji: „Aby tę rozdętą pisaninę wniosków (grantowych) przerwać, należałoby zwiększyć uniwersytetom podstawowe środki finansowe, które zostały umniejszone na rzecz innych źródeł finansowania”. Wezwanie to wspiera także autor niniejszej książki, który sam takie środki, i to znaczące, pozyskiwał. Nigdy jednak nie zgadzał się z czczą gadaniną 'wnioskową', z frazesami typu 'interdyscyplinarność, umiędzynarodowienie, innowacyjność i im podobnymi. Prace wykopaliskowe na przykład niekoniecznie zyskują na jakości dlatego, że są 'międzynarodowe'. Oczywiście włączenie do badań wybitnych naukowców z innych krajów jest rzeczą jak najbardziej pozytywną i korzystną. W przypadku wykopalisk w Troi są to jednak przypadki całkowicie jednostkowe. Przeważnie chodzi o uczestników z innych krajów, w przypadku których ich przygotowanie $\mathrm{w}$ zakresie archeologii naukowej uznać można za problematyczne. Dla odmiany szczególnie uzdolnieni badacze z Niemiec i innych krajów bardzo szybko wycofali się z Projektu Troja, albo też, ze względu na krnąbrną postawę, zostali z niego usunięci.

Zdobywanie finansów, sponsoring, obecność w mediach, popularyzowanie czy wręcz dążenie do osiągnięcia zysków komercyjnych, uznawane są przez polityków i konsultantów naukowych, zwłaszcza jednak przez kierownictwa uniwersytetów, za cele warte starań, aby nie powiedzieć: za najważniejsze cele nauki. Rektorów uniwersytetów interesuje w dzisiejszych czasach przede 
wszystkim kwota pozyskanych pieniędzy. Wynik sfinansowanych w ten sposób badań nie podlega niemalże żadnej kontroli, nie wzbudza także zainteresowania, chyba że nadaje się do ogłoszenia w mediach jako sensacja, służąc tym samym 'prestiżowi' uniwersytetu. Jaskrawym tego przykładem, jednym z wielu, jest postawa rektora Uniwersytetu Tybińskiego, Eberharda Schaicha, w kontekście sporu o Troję.

Nie dziwi w tej sytuacji, że tendencja do wyrzucania za burtę (wszelkich) zasad postępowania naukowego nabiera charakteru powszechnego. Chodzi tu o te kategorie i wartości, „które niegdyś ustanowiono, aby zagwarantować nauce taki status poznawczy, kulturowy i społeczny, który [...] ciągle musi być od nowa wypracowywany"19. W Stanach Zjednoczonych przeprowadzono anonimowe badania na grupie siedmiuset przedstawicieli nauk biomedycznych, które wykazały, że jedna trzecia z nich przejawia postawę nierzetelną ${ }^{20}$. Seria skandali, które miały miejsce w ostatnich 10-15 latach, dowodzi, że Niemcy także nie są od tego zjawiska wolne. Ogłoszony przez Niemiecką Wspólnotę Badawczą (Deutsche Forschungsgemeinschaft) projekt zasad, mających dać gwarancję właściwej praktyki naukowej, był reakcją na szczególnie drastyczne przypadki jej łamania. Dziesięć lat później Ulrike Beisiegel, członkini utworzonego wówczas zespołu rzeczników Niemieckiej Wspólnoty Badawczej, stwierdziła, że „memoriał ten jest dzisiaj tak samo ważny, jak w chwili jego ogłoszenia a w kręgach naukowych ciągle niedostatecznie znany i słabo zakorzeniony". Następnie uznała, że „wrażliwością wykazać się muszą przede wszystkim kierownicze gremia uniwersyteckie, które dotąd, zamiast wspierać właściwą postawę w obrębie badań naukowych i zdecydowanie potępiać wszelkie przejawy jej naruszania, tuszują każde wątpliwe, odbiegające od normy zachowanie, nie mówiąc już o jego napiętnowaniu". Krętactwa ukrywane są jednak nie tylko przez różne uniwersyteckie wydziały i instytuty, które wszelkie oszustwa zamiatają pod dywan. Oto co zauważa Holger Wormer, długoletni dziennikarz w Süddeutsche Zeitung, zajmujący się sferą życia naukowego oraz profesor dziennikarstwa na Uniwersytecie Dortmundzkim: „Nie wszędzie w środowisku

${ }^{19} \mathrm{M}$. Hagner, Bye-bye Science, Welcome Pseudo-Science? Reflexionen über einen beschädigten Status, [w:] D. Rupnow et alii, Pseudowissenschaft, s. 50; zob. także apel prezydenta Niemieckiego Związku Szkół Wyższych (Deutscher Hochschulverband), skierowany do odpowiedzialnych gremiów politycznych, aby „zdystansowały się od związków z postawami naukowo nieetycznymi oraz od wzrastającego nacisku konkurencji” (Newsletter 4/2010).

${ }^{20}$ Komunikat prasowy Niemieckiego Związku Szkół Wyższych z 16.06.2005; Frankfurter Allgemeine Zeitung, 15.06.2005. 
akademickim zauważa się gotowość do gruntownego poznania tych rzeczy [...]. Uniwersytet, który skazany jest na pozyskiwanie dodatkowych źródeł finansowania, nie za bardzo zainteresowany jest podejmowaniem poważnych działań przeciwko swemu pracownikowi. Nie byłoby bowiem rzeczą korzystną upublicznienie wiadomości, że na przykład któryś z renomowanych profesorów od lat fałszuje swoje badania”. Karana jest raczej ta osoba, która skandal ujawniła. „Nadzwyczaj smutnym doświadczeniem jest fakt, że najwyraźniej 'wszystkiemu winny’ staje się po części demaskator”, konkluduje Ulrike Beisiegel. Traktuje się go jako denuncjatora, jako tego, który kala własne gniazdo. Zarzuca mu się, że zazdroszcząc koledze sukcesu, podkłada mu nogę. „To właściwie demaskator uchodzi za tego, kto łamie istniejące zasady”. Tak to wygląda „w warunkach systemu, w którym najwyższą wartość stanowią przyjacielskie konszachty"21.

Nie jest wcale przypadkiem, że często lub nawet $\mathrm{z}$ reguły skandale ujawniane są nie przez ustanowione na uniwersytetach komisje do przestrzegania właściwych zasad postępowania naukowego, lecz przez prasę. Frankfurckiemu paleoantropologowi Reinerowi Protsch von Zieten zarzucono, że przy ustalaniu wieku kości ludzi pierwotnych przyjął „w całości absolutnie fałszywe dane”. Jego kolega, profesor Wighart von Koenigswald z Uniwersytetu w Bonn, spytany, dlaczego kwestie te nie zostały wyjaśnione drogą dyskusji naukowej, odpowiedział, że „laboratorium pana Protscha od dawna nikt już nie traktował poważnie [...]. Nauka nie ma w tym specjalnego interesu, aby światu pokazywać swoją czarną owcę". To zasługą magazynu Der Spiegel jest upublicznienie, że naukowcy Uniwersytetu w Getyndze środki na badania zdobyli podstępem, podając fałszywe dane. Chodzi tu o uczestników specjalnego programu badawczego, od roku 2000 finansowanego przez Niemiecką Wspólnotę Badawczą. Dopiero w lutym 2009 wyszło na jaw, przy opiniowaniu programu, że wcześniej podano fałszywe dane dotyczące publikacji, z których część została po prostu wymyślona ${ }^{22}$.

Należy oczywiście postawić sobie pytanie, dlaczego opiniodawcy Niemieckiej Wspólnoty Badawczej i innych instytucji wspierających działalność naukową występki takie, jeśli w ogóle, odkrywają i pociągają ich sprawców tak późno do odpowiedzialności? Lub też, jak było w przypadku Projektu Troja, spraw

\footnotetext{
${ }^{21}$ Cytaty pochodzą z: Forschung 2, 2008, s. 2-3; Deutsche Universitätszeitung (DUZ), Magazin 4, 2007, s. 36-37; Milos Vec, Frankfurter Allgemeine Zeitung, 25.02.2009.

${ }^{22}$ Przypadek Protscha: Frankfurter Allgemeine Zeitung, 18.08.2004; skandal getyński: Der Spiegel, 04.05.2009; zob. także Frankfurter Allgemeine Zeitung, 30.12.2009; Newsletter 4/2010 Niemieckiego Związku Szkół Wyższych (Deutscher Hochschulverband).
} 
tych się nie porusza, a jeśli już, to z zaleceniem skorygowania dotychczasowych wyników badań poprzez dalsze finansowanie prac wykopaliskowych?

Odpowiedzi udzielił Klaus Fischer, w wykładzie wygłoszonym w trakcie plenarnego posiedzenia na spotkaniu przedstawicieli (niemieckich) Wydziałów Filozoficznych, które odbyło się na Uniwersytecie w Tybindze 27-29 listopada 2008 roku. Stwierdził wówczas, że jest to „niestety tylko pobożne życzenie, aby naukowcy oceniali artykuły, książki i wnioski badawcze ich 'peers' (czyli kolegów), nie bacząc na osobę, instytucję czy związki paradygmatyczne”. Badania pokazują, że „słabość funkcjonowania systemu oceniania nauki [...] jest wprost porażająca [...]. Wyniki są tym bardziej alarmujące, że sposób oceniania przez fachowe czasopisma i instytucje dofinansowujące naukę jest w gruncie rzeczy taki sam. Można przypuszczać, że inne źródła finansowania, pozyskane dzięki systemowi, który, jak dowiedziono, jest w wielu przypadkach, jeśli chodzi o ocenę jakości, niewydolny i sam w sobie podlega różnym deformacjom, nie może być $[\ldots]$ wiarygodną miarą wkładu badawczego"23.

W małych dyscyplinach, takich właśnie, jak archeologia praktyczna, w których badacze, łącznie z recenzentami, nawzajem się znają, często się przyjaźnią lub powiązani są różnymi interesami, trudno jest oczekiwać opinii niezależnej. Archeolodzy, w rozmowach w cztery oczy, na moje zarzuty, że byli zbyt mało krytyczni wobec Projektu Troja, odpowiadali krótko: „kruk krukowi oka nie wykole”. Co można w tej sytuacji sądzić? Na pewno nie jest tak, że takie postępowanie, jakie znamy z wykopalisk w Troi, jest zjawiskiem powszechnym. Byłoby jednak korzystne, gdyby w przypadku prowadzonych konkretnych badań wykopaliskowych w sposób jasny precyzowano, jakie postępowanie i przestrzenie interpretacyjne są metodycznie i etycznie uzasadnione. W żadnym wypadku nie można akceptować, aby w dyskusji o wykopaliskach w Troi ukrywano sprawców niewłaściwych zachowań, jak również nie można pozwolić na to, aby z tych, którzy odsłonili nieprawidłowości, czyniono kozły ofiarne. Spór o Troję nie był ani „niegodny”, ani „zbędny”, ani „zbyt nagłośniony”, a ton krytyki, wbrew częstym zarzutom, wcale nie był utrzymywany na niewłaściwym poziomie ${ }^{24}$. Wręcz przeciwnie: to traktowany jako normalny ton dyskusji naukowej byłby, w sytuacji takiej, jak ujawnienie skandalu wokół Troi, czymś całkowicie niestosownym. Nie spotkałby się też z żadnym odzewem. Manfred Korfmann przeszedłby nad nim do porządku dziennego i swoje badania wy-

\footnotetext{
${ }^{23}$ Hochschulpolitische Informationen des Philosophischen Fakultätentages. Geistes-, Kulturund Sozialwissenschaften, wyd. 6. z października 2009.

${ }^{24}$ Zob. na przykład U. Veit, Über die Grenzen, s. 546, przyp. 2.
} 
kopaliskowe zakończyłby, jak planowano, w roku 2002, wieńcząc je triumfalną wystawą o Troi. Zasługą właśnie tego tonu krytyki, a nie tak bardzo pożądanej przenikliwości opiniodawców i innych kolegów Manfreda Korfmanna, jest to, że wykopaliska są kontynuowane. Prowadzi je się co prawda po to, aby dowieść tego, co założono, ale nie znaleziono.

W przychylnym wspomnieniu pośmiertnym o Manfredzie Osmanie Korfmannie, napisanym przez Haralda Hauptmanna, można dopatrzyć się pośredniej, ostrożnej krytyki zmarłego, ale także, przy dokładnej lekturze, wyraźnej aluzji do dokonanej przez niego błędnej oceny wyników prac wykopaliskowych. Do następców natomiast skierowana została życzliwa rada: „Zyskujecie szansę, mając na uwadze zachowane źródła archeologiczne, dokonania rozważnej oceny rzeczywistego znaczenia [podkr. autora] owych owianych mitami ruin"25. Szansa ta mogłaby wyglądać następująco: należałoby rzeczowo, bez zniekształcania wyników, otwarcie pokazać, jakie problemy wiążą się z rekonstrukcją historyczną na bazie (jedynie) badań archeologicznych; następnie skonfrontować nie tylko te spektakularne, ale całość wyników badań na wzgórzu Hisarlik zarówno z eposami Homera, jak i z innymi ważnymi, względnie najbardziej znaczącymi osiedlami zarówno Anatolii, jak i basenu Morza Egejskiego! W ten sposób można by się przyczynić do wyjaśnienia historycznego problemu, pozostającego w obłokach mitu.

Czy nadzieje Haralda Hauptmanna ziściły się? Czy jego uprzejmy apel spotkał się z odzewem? Niestety nie do końca. Ze strony kierownictwa Projektu Troja brakuje jak dotąd rzeczywistego rozliczenia się z grzechów popełnionych w erze Korfmanna. Wprawdzie tu i ówdzie pojawia się stwierdzenie, że w części krytyka była uzasadniona, ale ciągle dochodzi do pomysłów fantazyjnych, jak chociażby owa fikcyjna palisada $\mathrm{z}$ wałem ziemnym czy absurdalne liczby mieszkańców, bądź rozpowszechnianie nieprawdziwych stwierdzeń, czego przykładem jest rzekoma brama wjazdowa. Nie stanowi żadnego wytłumaczenia, a raczej jest samo w sobie symptomatyczne, że po Manfredzie Korfmannie profesurę w zakresie archeologii pradziejowej oraz kierownictwo nad badaniami wykopaliskowymi objął nie-archeolog Ernst Pernicka. Dla niego opinia o Manfredzie Korfmannie, najlepiej wyrażona w poświęconym mu przez Joachima Latacza nekrologu, musi mieć bez wątpienia znaczenie szczególne: „Odkrycia, których dokonał, nie zostały przez niego wyczarowane; one do nie-

${ }^{25}$ H. Hauptmann, Mitteilungen der Deutschen Orient-Gesellschaft zu Berlin 138, 2006, s. 5-10 (cytat na s. 10). 
go przyszły". I oto Ernstowi Pernicka przypadło w udziale ponowne odkrycie rowów Manfreda Korfmanna. Sprawozdawca (z wykopalisk) skomentował to następująco: „Rowy fortyfikacyjne pomagają w umocnieniu reputacji”. W ten oto sposób Ernst Pernicka stał się w jego relacji „ostatnim spadkobiercą Schliemanna"26.

Wysoce irytującego obrazu, stworzonego przez zespół prowadzący wykopaliska w Troi, nie są w stanie zmienić, objętościowo na pierwszy rzut oka imponujące, tymczasowe sprawozdania z wykopalisk, publikowane w Studia Troica. Dokładna ich lektura każe się jednak zastanowić, po co w ogóle prowadzić badania wykopaliskowe, skoro także bez nich można stwierdzić, że "wszystko już było". Jeśli celem, do którego wykorzystuje się wyniki prac wykopaliskowych, jest zamaskowanie tego, co naprawdę znaleziono, to wówczas całkowicie odpowiada to stwierdzeniu, że „kłamstwo, aby być wiarygodne [...]", potrzebuje „sprawdzonych detali”27. Jednak w przypadku tych wykopalisk detale nie składają się, niczym kostki mozaiki, na obraz wielkiego, datowanego na okres późnego brązu, „ważnego geopolitycznie miasta rezydencjonalnego i handlowego, położonego na styku Europy i Anatolii”. Również i dzisiaj odwiedzający teren wykopalisk na wzgórzu Hisarlik znajdzie, jak trafnie to sformułował Trevor Bryce, „miejsce niewywierające specjalnego wrażenia, które w oczach osoby, będącej tam po raz pierwszy, jest zaskakująco małe [...]. Gdyby pozbawić je skojarzeń mitycznych, to z dużym prawdopodobieństwem miejsce to straciłoby swych sponsorów, a wątpliwe jest, czy w przewodnikach turystycznych opatrzone byłoby chociaż jedną gwiazdką"28. Stwierdziliśmy już, że «Troja» nie jest żadnym miejscem historycznym, lecz fikcyjnym, i stanowi wynik i punkt odniesienia mitycznych, literacko-poetyckich, (pseudo)naukowych i polityczno-ideologicznie motywowanych działań. Gdyby sprawę tę potraktować bagatelizująco i z humorem, to można by odwołać się do krytycznej postawy antycznego pisarza Lukiana, ale z pewną korektą: Homer pod postacią wielbłąda żył nie w Baktrii, lecz w Tybindze. Gdyby kierownictwo wykopalisk w Troi było rozważne, to nie broniłoby zażarcie Korfmannowej wizji nadmuchanej Troi-kukły — wielkiego, znaczącego miasta, lecz jako osiągnięcie uwypukliłoby rzeczywisty wynik prac wykopaliskowych, a mianowicie, że dzięki nim wykazano, iż trwają-

\footnotetext{
${ }^{26}$ J. Latacz, Studia Troica 15, 2005, s. VIII; H. Baykal, Die Zeit 38, 2006; zob. także 37, 2006.

${ }^{27}$ U. Hölscher, Die Odyssee, wyd. 2, München 1989, s. 211.

${ }^{28}$ T. Bryce, The Trojans and their Neighbours, London-New York 2006, s. XII.
} 
ce dziesięciolecia daremne wysiłki zmierzające do udowodnienia istnienia wielkiego miasta i związane z tym przypuszczenia Schliemanna, Dörpfelda, Blegena - oraz twierdzenia Korfmanna - zostały odrzucone, a dzięki temu raz na zawsze stało się rzeczą jasną, że Homerowy obraz wspaniałego Ilionu jest poetycką fikcją, a nie rezultatem historycznej refleksji. Byłaby to wówczas nauka w służbie oświeceniowej interpretacji historycznej, a nie pseudonauka w służbie nowego tybińskiego mitu trojańskiego.

Wokół «Troi» mógłby więc wreszcie zapanować pokój, co paradoksalnie odpowiadałoby życzeniom Manfreda Korfmanna, który Troadę ogłosił regionem pokoju. Apel ten spotkał się z pozytywnym oddźwiękiem Hüseyina Baranera, który doprowadził do rozkwitu w Niemczech przedsiębiorstwa turystycznego Öğer-Tours, przez co przyczynił się do przekształcenia wybrzeża w okolicy Antalyi w zabudowane eldorado turystyki all inclusive. Ten obrotny przedsiębiorca, urodzony w Çanakkale nad Cieśniną Dardanelską, mówi o sobie: „Jestem Trojaninem”. W sierpniu 2005 roku zorganizował w Çanakkale konferencję, z udziałem archeologów pracujących w Troi i polityków, na temat „Pokój i turystyka", aby Troadę uatrakcyjnić z punktu widzenia turystyki ${ }^{29}$. Realizacja tego projektu stworzyłaby ponętną okazję do ucztowania, przy niemieckim jedzeniu i tureckiej muzyce, w pięciogwiazdkowym hotelu „Pokój Trojański”, aby, zgodnie z intencją Manfreda Korfmanna, świętować ostateczne zespolenie się islamu z chrześcijaństwem oraz włączenie tureckiego konia trojańskiego do Unii Europejskiej. Byłoby to zarazem świętowanie odrodzenia Troi, tyle że nie metropolii handlu, lecz wielkiego centrum turystyki.

Czytelnikom tej książki pragnąłbym na zakończenie udzielić dwóch rad. Jeśli ktoś chciałby odwiedzić homerycki Ilion, to nie znajdzie go ani w Cylicji Raoula Schrotta, ani na wzgórzu Hisarlik. Oszczędźmy sobie trudu, pozostańmy w domu i czytajmy Iliadę! Tam, i tylko tam znajdziemy Homerowy Ilion. Gdyby ktoś jednak szukał Troi, to powinien udać się w podróż do północnych Niemiec, a mianowicie do Meklemburgii-Pomorza Przedniego. Tuż nad granicą z Brandenburgią, niedaleko Ankershagen, gdzie Henryk Schliemann mieszkał jako mały chłopiec, znajdował się niegdyś przy starej drodze handlowej Zajazd Krümmel. Pełnił on zarazem funkcję stacji wymiany koni. U schyłku XVIII wieku miejscowość, przy której ów gościniec leżał, nosiła nazwę Troja.

\footnotetext{
${ }^{29}$ Tageszeitung, 07.05. 2005 (z cytatami).
} 
Dlaczego, nie wiadomo. Jednakże jedno jest pewne: Krümmel Krug wraz z Troją był węzłowym miejscem handlu! ${ }^{30}$

Autor tej książki nie oferuje bynajmniej ostatecznego „rozwiązania starej zagadki”. Obawiam się przy tym, że rację miał Dion Chryzostom, grecki retor z czasów rzymskich, gdy w "Mowie Trojańskiej, czyli o tym, że Ilion nie zostało zdobyte", przesyconej po części szkolną retoryką, mowie, którą rzekomo wygłosił w samym Ilionie, następująco skrytykował Homerowe przedstawienie wojny trojańskiej ${ }^{31}$ : „Jestem niemal pewien, że uczyć ludzi jest zawsze trudno, a oszukiwać łatwo. [...]. Dla nierozumnych bowiem prawda jest gorzka i niemiła, kłamstwo zaś słodkie i przyjemne. [...]. Jeśli — jak powiedziałem trudno jest ludzi uczyć, to pod każdym względem trudniej jest oduczać, jeśli ktoś przez długi czas słuchał i nie tylko on sam dał się wprowadzić w błąd, ale i ojciec jego, i dziad, i niemal wszyscy przodkowie. Nie jest rzeczą łatwą wykorzenić błędne mniemanie, nawet gdyby się całkowicie dowiodło jego fałszywości” (przekł. zbiorowy pod red. Kazimierza Kumanieckiego). Prawdopodobnie trudno będzie przekonać zwolenników mitu o Troi, że rację ma archeolog Rolf Hachmann, gdy mówi, że archeologia, zamiast przyczynić się do rozwiązania problemu trojańskiego, wywołała jeszcze więcej zamętu. Również słuszna jest jego ocena badań wykopaliskowych Manfreda Korfmanna, gdy twierdzi, że owo „wzgórze przeznaczenia archeologii” ${ }^{32}$ stało się swoistym „wzgórzem skandalu" tej dyscypliny. W książkach popularyzujących Troję, zwłaszcza autorstwa bazylejskiego grecysty Joachima Latacza, a także w przekazach medialnych, mamy do czynienia z nową interpretacją historii Troi w duchu „nowych szat króla”. Powinny one jednak pozostać w zgodzie z założeniem, że „nie wolno nam wychodzić poza standardy [naukowości], które wielokrotnie były formułowane i sprawdzane przez pokolenia uczonych humanistów"33.

\footnotetext{
${ }^{30}$ Troja w Meklemburgii: Frankfurter Allgemeine Zeitung, 14.11.2001; Schweriner Volkszeitung, 03-04.07.2004, s. 3 (z nazwą miejscowości, ale błędnym wyjaśnieniem); w tej kwestii dziękuję szczególnie Peterowi Jablonce za słuszne wskazanie na kalendarz państwowy Meklemburgii-Szwerina z roku 1793, który cytuje Udo Funk, zob. http:/www.geschichtsspuren.m-vp. de/thema09.htm.

${ }^{31}$ Dion Chryzostom, Mowa 35, 11.1-3.

${ }^{32}$ „Wzgórze przeznaczenia archeologii” - M. Siebler, Frankfurter Allgemeine Zeitung, 29.05.1990; por. Spektrum der Wissenschaft, lipiec 2000, s. 68.

${ }^{33}$ J. Cobet, H.-J. Gehrke, Warum um Troia immer wieder streiten?, Geschichte in Wissenschaft und Unterricht 53, 5-6, 2002, s. 316.
} 


\section{Frank Kolb \\ ON VIOLATING FUNDAMENTAL PRINCIPLES OF SCIENTIFIC CONDUCT}

\section{'Archaeology's Hill of Destiny' a Mountain of Scandal}

\section{Summary}

We are paying a high price for the increasingly unequivocal equation drawn between knowledge and science and ordinary market product. The ideal of perfectly unrestrained cognition, the true mother of science, is threatened by the mass drive towards practical use and application of knowledge, a looming departure into nothingness. Politicians and managers of scientific life are guilty of considerable contribution in corrupting respectable university structures, and thus undermining culture of science and scholarly ethics. Acquisition of funds, sponsorship, media presence, popularisation or even striving for commercial gain are recognised by politicians and scientific consultants, but most of all they are accepted by the university management as objectives worthy of effort, not to say the foremost goals of science. University rectors are nowadays interested primarily in the amounts of acquired moneys. The outcomes of research thus financed is subject to virtually no control, nor does it arouse any interest, unless it turns out to be fit to be announced in the media as a sensation, thereby serving the 'prestige' of the university. 
